\title{
Program Office
}

National Cancer Institute

\section{Source}

National Cancer Institute. Program Office. NCI Thesaurus. Code C62519.

An administrative unit established to oversee efforts that transcend organizational

boundaries. 